JIIA, VOLUME 6, No. 1, FEBRUARI 2018

\title{
STRATEGI PENGEMBANGAN TERNAK AYAM RAS PETELUR DI KECAMATAN GADINGREJO KABUPATEN PRINGSEWU
}

(Development Strategy of Layer Chichen Farming in Gadingrejo Subdistrict of Pringsewu Regency)

Suf Ajizah, Sudarma Widjaya, Suriaty Situmorang

Jurusan Agribisnis, Fakultas Pertanian, Universitas Lampung, Jl. Prof. Dr. Soemantri Brojonegoro No.1

Bandar Lampung 35141, Telp. 089661754370, e-mail: suf.ajizah@ gmail.com

\begin{abstract}
The research aims to determine the position strategy and the priority strategy of layer chicken farming development strategy. The research is a case study of layer chicken farming in Gadingrejo Subdistrict of Pringsewu District which has been chosen purposively. Data were collected in Desember 2016. Respondents were three farmers consist of large scale, medium scale, and small scale farmers. The analytical tool SWOT analysis was used in this study. The results showed that large scale, medium scale, and small scale of layer chicken farming businesses were in quadrant I with the position of aggressive growth strategy. The development priority strategy of large scale is to increase relationships with suppliers so that the development of chicken livestock centers can be achieved. The development priority strategy of medium scale is to improve customers so that farmers are able to compete. The development priority strategy of small scale is to maintain a strategic location for easy reaching and meet the demand of eggs by costumers.
\end{abstract}

Key words: development strategy, layer chickens, SWOT analysis

\section{PENDAHULUAN}

Usaha ternak ayam ras petelur memiliki prospek yang besar untuk dikembangkan di Provinsi Lampung, karena kebutuhan masyarakat akan telur ayam cukup tinggi. Telur ayam merupakan salah satu sumber protein hewani yang memiliki nilai gizi yang baik dan lebih murah dibandingkan produk ternak yang lain, sehingga dapat menjangkau lebih luas masyarakat di Indonesia. Komposisi zat gizi telur ayam yang lengkap dan harganya yang relatif terjangkau membuat telur ayam sebagai pilihan bahan makanan sumber zat gizi untuk meningkatkan kualitas dan kesehatan tubuh masyarakat. Harga telur ayam yang relatif terjangkau mendorong konsumen dalam melakukan pembelian telur ayam. Tingginya tingkat konsumsi telur ayam ras petelur tidak diikuti oleh peningkatan produksi telur, sehingga pada tahun 2015-2019 diproyeksikan terjadi defisit penawaran telur (Badan Pusat Statistik Indonesia 2016).

Kondisi ini memberikan peluang bagi peternak dalam mengembangkan usahanya dengan harapan dapat memenuhi permintaan telur oleh masyarakat. Selain itu, kondisi ini juga dapat menjadi ancaman bagi peternak yang sudah ada, karena akan banyak pengusaha yang mendirikan usaha ternak ayam ras petelur yang baru dan menambah pesaing yang berasal dari usaha ternak yang sejenis.

Kabupaten Pringsewu adalah salah satu kabupaten yang memiliki populasi ayam ras petelur yang tinggi dan diikuti dengan penambahan produksi telur yang tinggi pula. Kecamatan Gadingrejo merupakan kecamatan di Kabupaten Pringsewu dengan populasi dan produksi paling besar dibandingkan dengan kecamatan lain, yaitu sebesar 68,62\% (Badan Pusat Statistik Kabupaten Pringsewu 2016). Hal ini menunjukkan bahwa peluang Kecamatan Gadingrejo untuk menjadi sentra ternak ayam ras petelur yang sangat besar.

Usaha ternak ayam ras petelur di Kabupaten Pringsewu dihadapkan pada masalah tingginya biaya produksi, khususnya biaya pakan sebesar $83,58 \%$ dari total biaya produksi yang dikeluarkan oleh peternak dalam satu periode produksi (Badan Pusat Statistik Kabupaten Pringsewu 2016). Keberlangsungan usaha ternak ayam ras petelur dipengaruhi oleh besarnya biaya produksi yang dikeluarkan. Inflasi yang terjadi menyebabkan harga-harga faktor produksi meningkat dan berdampak pada peningkatan biaya produksi. Peningkatan biaya produksi akibat peningkatan biaya pakan menyebabkan harga pokok produksi meningkat, sehingga pada harga jual tetap akan berdampak pada penurunan keuntungan peternak 


\section{JIIA, VOLUME 6, No. 1, FEBRUARI 2018}

(Saragih 2010). Kelemahan peternak adalah tidak adanya kemampuan peternak untuk menciptakan pakan ternak sendiri untuk mengatasi tingginya biaya pakan.

Peningkatan biaya produksi juga mempengaruhi sikap peternak dalam keputusan mengalokasikan input. Peternak dapat mengganti input dalam hal ini pakan dengan jenis pakan lain atau mengurangi kuantitas maupun kualitas pakan. Peternak memiliki pemasok tetap yang dapat memasok pakan, sehingga menjadi kekuatan peternak dalam memenuhi kebutuhan pakan ternak. Peningkatan biaya produksi usaha ternak ayam ras petelur di Kecamatan Gadingrejo Kabupaten Pringsewu juga menyebabkan peternak harus meningkatkan harga jual telur. Perubahan harga telur ayam ras petelur yang cenderung meningkat mempengaruhi permintaan dan keputusan konsumen dalam mengonsumsi telur ayam. Konsumen dapat mengambil keputusan untuk mengurangi jumlah konsumsi telur, mengganti telur dengan produk ternak lain yang lebih murah, atau mengganti telur dengan produk sumber protein nabati.

Kondisi tersebut dapat menjadi peluang usaha sekaligus ancaman bagi peternak karena akan menurunkan keuntungan peternak dan berdampak pada keberlanjutan usaha ternak di masa yang akan datang. Oleh sebab itu penelitian ini bertujuan untuk mengetahui posisi strategi usaha dan strategi prioritas pengembangan yang dapat diterapkan untuk menjamin keberlanjutan usaha ternak ayam ras petelur di Kecamatan Gadingrejo Kabupaten Pringsewu.

\section{METODE PENELITIAN}

Penelitian ini dilaksanakan dengan metode studi kasus pada tiga peternak, masing-masing berasal dari peternak skala besar, skala menengah, dan skala kecil di Kecamatan Gadingrejo Kabupaten Pringsewu dengan pertimbangan bahwa peternak tersebut adalah peternak yang berhasil dan sukses menjalankan usaha ternaknya. Pengambilan data penelitian dilakukan pada bulan Desember 2016. Data yang dikumpulkan terdiri dari data primer dan data sekunder yang bersifat kualitatif. Data primer diperoleh dari wawancara langsung dengan peternak menggunakan daftar pertanyaan (kuisioner), sedangkan data sekunder diperoleh dari peternak dan dari instansi terkait.

Posisi strategi usaha ternak ayam ras petelur diketahui melalui pendekatan lingkungan internal dan eksternal menggunakan diagram analisis
SWOT. Menurut Rangkuti (2006), faktor-faktor strategis sebuah perusahaan dapat disimpulkan dengan cara mengkombinasikan faktor strategis eksternal (peluang dan ancaman) dengan faktor strategis internal (kekuatan dan kelemahan) ke dalam sebuah ringkasan analisis faktor-faktor strategis. Komponen faktor internal adalah sarana dan prasarana, pendanaan atau modal, sumber daya manusia, manajemen, dan pemasaran, sedangkan komponen faktor eksternal adalah ekonomi, sosial dan budaya, teknologi, pesaing, dan kebijakan pemerintah. Menurut David (2009), perumusan strategi pengembangan usaha ternak ayam ras petelur dapat dilakukan dengan analisis SWOT menggunakan dua hasil identifikasi faktor internal dan eksternal yang disajikan pada matrik IFAS (Internal Factors Analysis Summary) dan matrik EFAS (Eksternal Factors Analysis Summary). Diagram SWOT diperoleh dengan membandingkan faktor internal dan eksternal, sehingga dapat menggambarkan posisi usaha ternak ayam ras petelur. Posisi strategi peternakan dalam memanfaatkan kekuatan, menangkap peluang, mengatasi kelemahan, dan menghadapi ancaman dapat dilihat pada kuandran I, II, III, dan IV. Diagram analisis SWOT seperti pada Gambar 1.

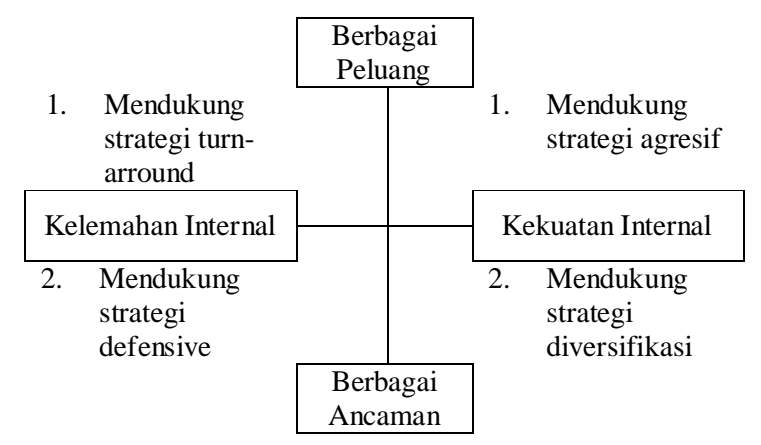

Gambar 1. Diagram analisis SWOT (David 2009)

Strategi prioritas pengembangan diperoleh dengan melakukan penyilangan faktor-faktor internal dan eksternal. Penyilangan untuk mengetahui strategi SO (Strengths-Opportunities), strategi SW (Strengths-Weaknesses), strategi WO (WeaknessesOpportunities), dan strategi WT (WeaknessesTreats (Solihin 2012). Hasil penyilangan kemudian dilakukan pendekatan terhadap visi dan misi usaha ternak ayam ras petelur untuk mendapatkkan skor dari masing-masing persilangan. Strategi yang tersusun selanjutnya diranking, dimana strategi yang paling mendukung visi dan misi akan mendapatkan ranking tertinggi atau ranking satu dan seterusnya. Ranking tertinggi atau ranking satu hingga ranking lima adalah strategi prioritas 
pengembangan usaha yang dianjurkan untuk segera diterapkan dalam usaha ternak ayam ras petelur untuk keberlanjutan usaha.

\section{HASIL DAN PEMBAHASAN}

\section{Budidaya Ternak Ayam Ras Petelur}

Ayam ras petelur adalah memiliki periode produksi selama 24 bulan atau dua tahun. Berdasarkan penelitian, tahapan budidaya ternak ayam ras petelur meliputi persiapan kandang, pemeliharaan, dan panen. Ayam ras petelur memiliki fase pertumbuhan, yaitu fase starter, fase grower, dan fase layer. Ayam petelur starter adalah ayam yang berusia nol sampai enam minggu. Ayam petelur grower adalah ayam yang berusia tujuh sampai 13 minggu, grower merupakan fase kontrol pertumbuhan dan penyeragaman. Ayam petelur layer atau developer adalah ayam yang berusia 14 sampai 20 minggu, pada fase ini pertumbuhan ayam sudah mulai menurun namun perkembangan reproduksinya meningkat. Ayam ras petelur akan bertelur berdasarkan usia produktif dan performa ayam. Performa adalah persentase kemampuan ayam untuk menghasilkan telur. Performa tertinggi ayam ras petelur adalah sebesar $96 \%$ pada usia 28 minggu, kemudian performa akan menurun sedikit demi sedikit seiring bertambahnya usia.

\section{Profil Peternak Ayam Ras Petelur}

Usaha ternak skala besar memiliki jumlah populasi ternak ayam ras petelur sebanyak 60.000 ekor. Rata-rata produksi telur yang dihasilkan per tahun sebesar $778.946 \mathrm{~kg}$, rata-rata ayam afkir yang dihasilkan per tahun sebanyak 25.850 ekor, dan rata-rata limbah ternak yang dihasilkan per tahun sebesar $167.407 \mathrm{~kg}$. Harga jual telur adalah Rp16.000,00 per kg, harga jual ayam afkir adalah Rp36.000,00 per ekor, dan harga jual limbah adalah Rp560 per kg.

Berdasarkan penelitian diketahui bahwa faktor produksi yang digunakan oleh ketiga skala usaha adalah sama dan dapat pada dilihat pada Tabel 1 .

Usaha ternak skala menengah memiliki jumlah populasi ternak ayam ras petelur sebanyak 10.000 ekor. rata produksi telur yang dihasilkan per tahun sebesar $139.619 \mathrm{~kg}$, rata-rata ayam afkir yang dihasilkan per tahun sebanyak 4.328 ekor, dan rata-rata limbah ternak yang dihasilkan per tahun sebesar $25.434 \mathrm{~kg}$. Harga jual telur adalah Rp15.800,00 per kg, harga jual ayam afkir adalah
Rp40.000,00 per ekor, dan harga jual limbah adalah Rp480 per kg.

Usaha ternak skala kecil memiliki jumlah populasi ternak ayam ras petelur sebanyak 5.000 ekor. rata produksi telur yang dihasilkan per tahun sebesar $63.505 \mathrm{~kg}$, rata-rata ayam afkir yang dihasilkan per tahun sebanyak 2.239 ekor, dan rata-rata limbah ternak yang dihasilkan per tahun sebesar 11.093 kg. Harga jual telur adalah Rp16.000,00 per kg, harga jual ayam afkir adalah Rp45.000,00 per ekor, dan harga jual limbah adalah Rp300 per kg.

\section{Matrik IFAS dan EFAS Usaha Ternak Ayam Ras Petelur}

Kerangka matrik IFAS dan EFAS disusun berdasarkan identifikasi bobot komponen lingkungan internal dan komponen lingkungan eksternal menggunakan tabel papan catur. Komponen lingkungan internal yang mempengaruhi usaha ternak ayam ras petelur di Kecamatan Gadingrejo terdiri dari komponen sarana dan prasarana, pendanaan atau modal, sumber daya manusia, manajemen, dan pemasaran. Komponen lingkungan eksternal yang mempengaruhi usaha ternak ayam ras petelur di Kecamatan Gadingrejo terdiri dari komponen ekonomi, sosial dan budaya, teknologi, pesaing, dan kebijakan pemerintah. Komponen lingkungan internal mengandung berbagai faktor-faktor internal (kekuatan dan kelemhan) dan komponen lingkungan eksternal mengandung berbagai faktorfaktor eksternal (peluang dan ancaman).

Tabel 1. Faktor produksi usaha ternak ayam ras petelur di Kecamatan Gadingrejo Kabupaten Pringsewu, tahun 2016

\begin{tabular}{ll}
\hline \multicolumn{1}{c}{ Komponen } & \multicolumn{1}{c}{ Uraian } \\
\hline Faktor produksi & $\begin{array}{l}\text { DOC, pullet, pakan, vaksin, } \\
\text { tenaga kerja, dan peralatan } \\
\text { budidaya }\end{array}$ \\
Jenis DOC & $\begin{array}{l}\text { ISA Brown dan Lohmann Brown } \\
\text { Pakan }\end{array}$ \\
$\begin{array}{l}\text { Jagung 50\%, dedak 17\%, dan } \\
\text { konsentrat 33\% }\end{array}$ \\
Vaksin & IB, Gumboro, ND, ILT, SNOT, \\
& Fowl Pox, dan EDS-76 \\
\hline
\end{tabular}


Pembobotan faktor-faktor internal dan faktorfaktor eksternal dilakukan dengan menggunakan papan catur untuk menghasilkan bobot pada masing-masing faktor, selanjutnya disusun dalam kerangka matrik. Komponen lingkungan internal pada skala besar adalah sarana/prasarana dan sumberdaya manusia sebesar 23 persen, skala menengah adalah manajemen sebesar 25 persen, dan skala kecil adalah sarana/prasaran sebesar 26 persen. Kerangka matrik faktor strategi iternal (IFAS) dan matrik faktor strategi eksternal (EFAS) untuk peluang dan ancaman pada ketiga usaha ternak skala besar, skala menengah, dan skala kecil dapat dilihat pada Tabel 3 dan Tabel 4 (terlampir).

Komponen lingkungan eksternal pada skala besar adalah ekonomi sebesar 27 persen, skala menengah adalah sosial dan budaya sebesar 26 persen, dan skala kecil adalah pesaing sebesar 23 persen. Skor strategi internal untuk faktor kekuatan yang terbesar pada skala besar adalah kerjasama dengan pemasok tetap dengan skor 0,56, pada skala menengah adalah tenaga kerja berpengalaman dengan skor 0,60 , dan pada skala kecil adalah lokasi usaha mudah dijangkau dengan skor 0,52. Skor strategi internal untuk kelemahan yang terbesar pada skala besar adalah keterbatasan dana untuk menambah lokasi usaha dan jumlah tenaga kerja yang kurang mencukupi dengan skor 0,24. Pada skala menengah adalah lokasi usaha dekat dengan pemukiman dengan skor 0,36 dan pada skala kecil adalah pemanfaatan teknologi masih rendah dengan skor 0,40 .

Skor strategi eksternal untuk faktor peluang yang terbesar pada skala besar dan skala kecil adalah proyeksi permintaan telur meningkat dengan skor 0,48. Pada skala menengah adalah lembaga keuangan terjangkau, tenaga kerja melimpah, dan informasi mudah diakses dengan skor 0,40. Skor strategi eksternal untuk faktor ancaman pada skala besar adalah inflasi harga sarana produksi ternak dengan skor 0,26. Pada skala menengah adalah peningkatan harga sarana produksi ternak, pesaing dari usaha sejenis, dan tidak adanya penjaminan stok pakan dengan skor 0,22 .

\section{Posisi Strategi Usaha Ternak Ayam Ras Petelur}

Selisih skor faktor internal dan faktor eksternal ketiga skala usaha ternak dapat dilihat pada Tabel 2. Sumbu x pada diagram SWOT adalah posisi kekuatan dan kelemahan, sedangkan sumbu y pada diagram SWOT adalah peluang dan ancaman. Hasil penelitian menunjukkan bahwa usaha ternak skala besar berada pada titik koordinat $(1,33 ; 1,30)$ pada diagram SWOT, usaha ternak skala menengah berada pada titik koordinat $(1,13 ; 1,19)$ pada diagram SWOT, dan usaha ternak skala kecil berada pada titik koordinat $(0,83 ; 0,70)$ pada diagram SWOT, dimana sumbu $X$ (kekuatan dan kelemahan) dan sumbu Y (peluang dan ancaman).

Hasil penelitian sejalan dengan penelitian Laisa, Sayekti, dan Nugraha (2013) tentang analisis harga pokok produksi dan strategi pengembangan industri pengolahan ikan teri nasi kering, yaitu selisih faktor internal lebih besar dibandingkan dengan faktor eksternal pada titik koordinat $(0,90 ; 0,45)$, sehingga pengusaha dinyatakan dapat menunjang keberlanjutan usahanya dengan menggunakan faktor internal yang dimiliki dengan baik.

Diagram SWOT usaha ternak ayam ras petelur skala besar dapat dilihat pada Gambar 2 .

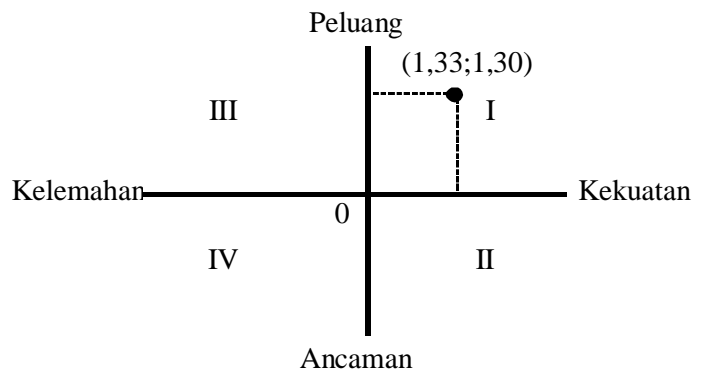

Gambar 2. Diagram SWOT usaha ternak ayam ras petelur skala besar di Kecamatan Gadingrejo, tahun 2016

Tabel 2. Selisih skor faktor internal dan faktor eksternal usaha ternak ayam ras petelur di Kecamatan Gadingrejo Kabupaten Pringsewu, tahun 2016

\begin{tabular}{|c|c|c|c|c|}
\hline \multirow{2}{*}{ Uraian } & \multicolumn{2}{|c|}{ Faktor internal } & \multicolumn{2}{|c|}{ Faktor ekstenal } \\
\hline & Kekuatan & Kelemahan & Peluang & Ancaman \\
\hline \multicolumn{5}{|c|}{ 1. Usaha Skala Besar } \\
\hline Skor & 2,34 & 1,01 & 2,07 & 0,77 \\
\hline Selisih & 1,33 & & 1,30 & \\
\hline \multicolumn{5}{|c|}{ 2. Usaha Skala Menengah } \\
\hline Skor & 2,26 & 1,13 & 2,00 & 0,81 \\
\hline Selisih & 1,13 & & 1,19 & \\
\hline \multicolumn{5}{|c|}{ 3. Usaha Skala Kecil } \\
\hline Skor & 2,00 & 1,17 & 1,58 & 0,88 \\
\hline Selisih & 0,83 & & 0,70 & \\
\hline
\end{tabular}


Diagram SWOT usaha ternak skala menengah dapat dilihat pada Gambar 3.

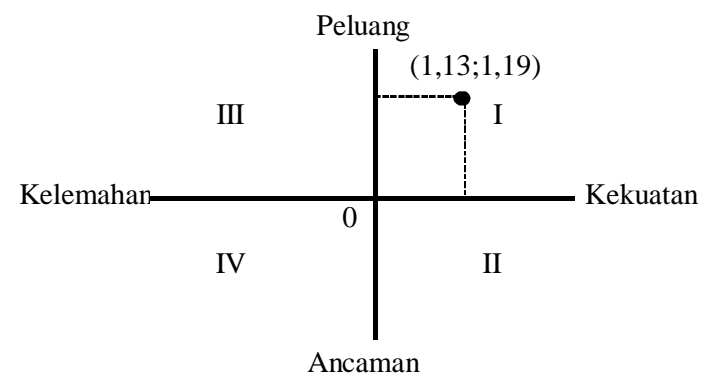

Gambar 3. Diagram SWOT usaha ternak ayam ras petelur skala menengah di Kecamatan Gadingrejo, tahun 2016

Diagram SWOT usaha ternak skala kecil dapat dilihat pada Gambar 4.

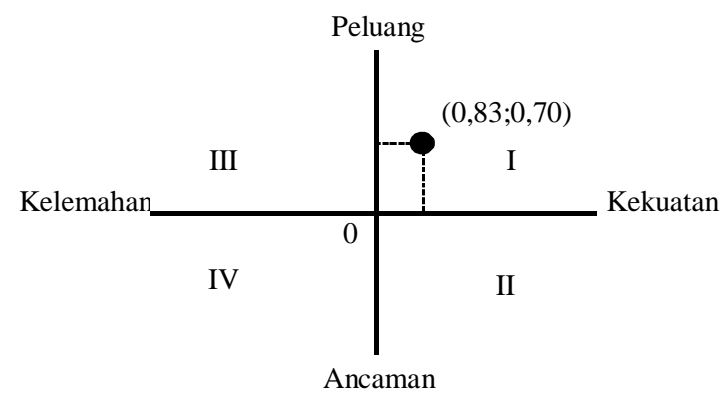

Gambar 4. Diagram SWOT usaha ternak ayam ras petelur skala kecil di Kecamatan Gadingrejo, tahun 2016

Berdasarkan selisih skor faktor internal dan faktor eksternal, kemudian dapat disimpulkan bahwa usaha ternak ayam ras peterlur skala besar, skala menengah, dan skala kecil berada pada kuadran I, yaitu pada posisi growth strategy yang artinya usaha ternak ayam ras petelur skala besar berada dalam situasi menguntungkan karena memiliki kekuatan dan memanfaatkan peluang yang ada. Strategi yang diterapkan dalam kondisi ini adalah mendukung kebijakan pertumbuhan yang agresif (Rangkuti, 2006). Hasil penelitian ini berbeda dengan penelitian Rizky, Haryono, dan Kasymir (2016) tentang analisis usaha dan strategi pengembangan ternak kalkun Mitra Alam, yaitu usaha ternak berada pada kuadran II dengan posisi diversification strategy, yaitu dalam kondisi mantap dan menghadapi sejumlah tantangan berat, sehingga akan sulit menjalankan usaha apabila bertumpu pada strategi sebelumnya.

\section{Strategi Pengembangan Ternak Ayam Ras Petelur}

Strategi adalah suatu cara yang digunakan untuk memperoleh keuntungan dan untuk mencapai tujuan perusahaan jangka panjang (Siagian 2000). Strategi alternatif pengembangan ternak ayam ras petelur di Kecamatan Gadingrejo Kabupaten Pringsewu dilakukan dengan pendekatan analisis SWOT (Strengths-Weaknesses-OpportunitiesTreats). Hasil penyilangan atau penggabungan faktor internal dan faktor eksternal melalui matrik SWOT menghasilkan strategi SO (StrengthsOpportunities), strategi SW (StrengthsWeaknesses), strategi WO (WeaknessesOpportunities), dan strategi WT (WeaknessesTreats.

Strategi prioritas pengembangan ternak ayam ras petelur di Kecamatan Gadingrejo Kabupaten Pringsewu dilakukan dengan pendekatan terhadap visi dan misi usaha ternak ayam ras petelur untuk mendapatkkan skor dari masing-masing persilangan sehingga didapatkan ranking dari strategi tersebut. Visi dan misi yang digunakan untuk analisis SWOT usaha ternak ayam ras petelur adalah visi dan misi yang mengacu kepada visi dan misi peternakan pada masing-masing skala usaha ternak. Strategi prioritas pengembangan ternak ayam ras petelur diambil dari strategi yang berada pada sepuluh strategi dengan peringkat tertinggi. Hal ini sejalan dengan penelitian Sari, Hudoyo, dan Nugraha (2015) tentang analisis finansial dan strategi pengembangan pedagang telur eceran, yaitu strategi utama pengembangan dipilih sebanyak lima strategi teratas dari hasil persilangan faktor strategi internal dan faktor strategi eksternal.

Strategi prioritas pengembangan usaha ternak ayam ras petelur skala besar adalah :

a. Meningkatkan kerjasama dengan pemasok tetap sehingga pengembangan daerah sentra ternak ayam ras petelur dapat tercapai.

b. Meningkatkan kerjasama dengan pemasok tetap sehingga peternak dapat menjadi distributor bibit dan pakan bagi peternak kecil di Kecamatan Gadingrejo.

c. Mempertahankan wilayah pemasaran yang luas dan memanfaatkan proyeksi permintaan telur yang meningkat.

d. Memperluas wilayah pemasaran sehingga peternak dapat melakukan pengembangan daerah sentra ternak ayam ras petelur 
e. Menggunakan ilmu dan pengetahuan yang dimiliki untuk dapat melakukan riset teknologi sederhana sendiri.

Strategi prioritas usaha ternak ayam ras petelur skala menengah adalah :

a. Mempertahankan pelanggan tetap sehingga peternak mampu bersaing dengan peternak lain.

b. Mengatasi keterbatasan dana untuk menambah jumlah kandang dengan memanfaatkan ketersediaan lembaga keuangan yang memberikan pinjaman modal.

c. Lokasi usaha dekat dengan pemukiman sehingga dapat menyediakan lapangan pekerjaan bagi masyarakat sekitar.

d. Memanfaatkan ketersediaan tenaga kerja yang melimpah sehingga tidak perlu melakukan pemasaran sendiri.

e. Tidak melakukan pemasaran sendiri dan peternak dapat menyediakan lapangan pekerjaan bagi masyarakat sekitar untuk memasarkan produk.

Strategi prioritas usaha ternak ayam ras petelur skala kecil adalah :

a. Menggunakan lokasi yang strategis dan mudah dijangkau dan memanfaatkan peningkatan permintaan telur.

b. Menggunakan pendanaan dari modal sendiri dan memanfaatkan ketersediaan lembaga keuangan dengan bunga kredit pinjaman rendah jika mengalami kekurangan modal.

c. Meningkatkan pelanggan tetap dan memanfaatkan peningkatan permintaan telur.

d. Menggunakan tenaga kerja yang berusia produktif dan memanfaatkan peningkatan permintaan telur.

e. Menggunakan lokasi yang strategis dan mudah dijangkau dan memanfaatkan potensi pengembangan daerah sebagai sentra ternak ayam ras petelur.

Berdasarkan lima strategi dari masing-masing skala usaha yang ada, maka selanjutnya direkomendasikan satu strategi teatas. Hal tersebut dilakukan dengan pertimbangan bahwa strategi tersebut sesuai dengan kondisi peternakan ayam ras petelur di Kecamatan Gadingrejo Kabupaten Pringsewu.

\section{KESIMPULAN}

Kesimpulan dari penelitian yang telah dilakukan adalah usaha ternak ayam ras petelur skala besar, skala menengah, dan skala kecil di Kecamatan Gadingrejo berada pada kuadran I dengan posisi strategi pertumbuhan secara agresif. Strategi prioritas pengembangan ternak ayam ras petelur skala besar adalah meningkatkan kerjasama dengan pemasok tetap sehingga pengembangan daerah sentra ternak ayam ras petelur dapat tercapai. Strategi prioritas pengembangan ternak ayam ras petelur skala menengah adalah mempertahankan pelanggan tetap sehingga peternak mampu bersaing dengan peternak lain. Strategi prioritas pengembangan ternak ayam ras petelur skala kecil adalah mempertahankan lokasi yang strategis dan mudah dijangkau dan memanfaatkan peningkatan permintaan telur.

\section{DAFTAR PUSTAKA}

Badan Pusat Statistik Indonesia. 2016. Distribusi Persentase Produk Domestik Bruto Triwulanan Seri 2010 Atas Dasar Harga Berlaku. http://bps.go.id. [31Agustus 2016].

Badan Pusat Statistik Kabupaten Pringsewu. 2016. Pringsewu dalam Angka. Pringsewu.

David FR. 2009. Manajemen Strategis. Salemba Empat. Jakarta.

Laisa DD, Sayekti WD, dan Nugraha A. 2013. Analisis harga pokok produksi dan strategi pengembangan industri pengolahan ikan teri nasi kering di Pulau Pasaran Kecamatan Teluk Betung Barat Kota Bandar Lampung. JIIA: 1(2), 111-117. http://jurnal. fp.unila.ac .id/index.php/JIIA/issue/view/01. [01 November 2016].

Rangkuti F. 2006. Analisis SWOT Teknik Membedh Kasus Bisnis. Gramedia Pustaka Utama Jakarta.

Rizky A, Haryono D, dan Kasymir E. 2016. Analisis usaha dan strategi pengembangan ternak kalkun mitra alam Kabupaten Pringsewu Provinsi Lampung. JIIA: 4(3), 235-242. http://jurnal.fp.unila.ac.id/index. php/JIIA/issue/view/01. [01 November 2016].

Saragih B. 2010. Pengembangan Agribisnis Ayam dalam MEA. Penerbit Permata Wancana Lestari. Jakarta.

Sari TY, Hudoyo A, dan Nugraha A. 2015. Analisis finansial dan strategi pengembangan usaha pedagang telur eceran: studi kasus di pasar tradisional Kota Bandar Lampung. JIIA: 3(3), 243-250. http://jurnal.fp.unila.ac.id/ index.php/JIIA/issue/view/01. [01 November 2016].

Siagian SP. 2000. Manajemen Strategik. Bumi Aksara. Jakarta.

Solihin I. 2012. Manajemen Strategik. Erlangga. Jakarta. 


\section{JIIA, VOLUME 6, No. 1, FEBRUARI 2018}

Tabel 3. Matriks IFAS (Internal Factors Analysis Summary) usaha ternak ayam ras petelur skala besar, skala menengah, dan skala kecil untuk kekuatan dan kelemahan di Kecamatan Gadingrejo, tahun 2016

\begin{tabular}{|c|c|c|c|c|c|c|c|c|c|c|c|}
\hline Skala Besar & Bobot & Rating & Skor & Skala Menengah & Bobot & Rating & Skor & Skala Kecil & Bobot & Rating & Skor \\
\hline \multicolumn{12}{|l|}{ A. Kekuatan } \\
\hline $\begin{array}{l}\text { 1. Kerjasama dengan } \\
\text { pemasok tetap }\end{array}$ & 0,14 & 4 & 0,56 & $\begin{array}{l}\text { 1. Memiliki pemasok sarana } \\
\text { produksi tetap }\end{array}$ & 0,12 & 3 & 0,36 & $\begin{array}{l}\text { 1. Lokasi usaha mudah } \\
\text { dijangkau }\end{array}$ & 0,13 & 4 & 0,52 \\
\hline $\begin{array}{l}\text { 2. Pendanaan dari modal } \\
\text { sendiri }\end{array}$ & 0,09 & 3 & 0,27 & $\begin{array}{l}\text { 2. Mampu menekan biaya } \\
\text { vaksin }\end{array}$ & 0,13 & 3 & 0,39 & $\begin{array}{l}\text { 2. Pendanaan dari modal } \\
\text { sendiri }\end{array}$ & 0,06 & 3 & 0,18 \\
\hline $\begin{array}{l}\text { 3. Peternak } \\
\text { berpendidikan tinggi }\end{array}$ & 0,08 & 4 & 0,32 & $\begin{array}{l}\text { 3. Tenaga kerja } \\
\text { berpengalaman }\end{array}$ & 0,15 & 4 & 0,60 & $\begin{array}{l}\text { 3. Tenaga kerja berusia } \\
\text { produktif }\end{array}$ & 0,11 & 4 & 0,44 \\
\hline $\begin{array}{l}\text { 4. Tenaga kerja terampil } \\
\text { dan berusia produktif }\end{array}$ & 0,09 & 3 & 0,27 & 4. Ada pembukuan usaha & 0,13 & 4 & 0,52 & 4. Ada pembukuan usaha & 0,11 & 4 & 0,44 \\
\hline $\begin{array}{l}\text { 5. Ada pembukuan } \\
\text { usaha }\end{array}$ & 0,06 & 3 & 0,18 & 5. Memiliki pelanggan tetap & 0,13 & 3 & 0,39 & 5. Memiliki pelanggan tetap & 0,14 & 3 & 0,42 \\
\hline $\begin{array}{l}\text { 6. Lokasi usaha tidak } \\
\text { dekat pemukiman }\end{array}$ & 0,10 & 3 & 0,30 & & & & & & & & \\
\hline $\begin{array}{l}\text { 7. Wilayah pemasaran } \\
\text { luas }\end{array}$ & 0,11 & 4 & 0,44 & & & & & & & & \\
\hline Jumlah & 0,67 & & 2,34 & & 0,66 & & 2,26 & & 0,55 & & 2,00 \\
\hline \multicolumn{12}{|l|}{ B. Kelemahan } \\
\hline $\begin{array}{l}\text { 1.Keterbatasan stok pakan } \\
\text { ternak ayam }\end{array}$ & 0,09 & 2 & 0,18 & 1. Keterbatasan lahan & 0,11 & 3 & 0,33 & 1. Stok pakan terbatas & 0,13 & 2 & 0,26 \\
\hline $\begin{array}{l}\text { 2.Keterbatasan dana untuk } \\
\text { penambahan lokasi usaha }\end{array}$ & 0,08 & 3 & 0,24 & $\begin{array}{l}\text { 2. Keterbatasan dana untuk } \\
\text { menambah jumlah kandang }\end{array}$ & 0,06 & 4 & 0,24 & $\begin{array}{l}\text { 2. Bunga kredit pinjaman } \\
\text { tinggi }\end{array}$ & 0,07 & 3 & 0,21 \\
\hline $\begin{array}{l}\text { 3.Tenaga kerja kurang } \\
\text { mencukupi kebutuhan }\end{array}$ & 0,06 & 4 & 0,24 & $\begin{array}{l}\text { 3. Tenaga kerja sebagian besar } \\
\text { wanita }\end{array}$ & 0,02 & 4 & 0,08 & $\begin{array}{l}\text { 3. Pemanfaatan teknologi } \\
\text { masih rendah }\end{array}$ & 0,10 & 3 & 0,40 \\
\hline $\begin{array}{l}\text { 4.Pemilik mengolah } \\
\text { pembukuan sendiri }\end{array}$ & 0,05 & 4 & 0,20 & $\begin{array}{l}\text { 4. Lokasi usaha dekat dengan } \\
\text { pemukiman }\end{array}$ & 0,12 & 3 & 0,36 & $\begin{array}{l}\text { 4. Lokasi usaha dekat } \\
\text { dengan pemukiman }\end{array}$ & 0,08 & 2 & 0,16 \\
\hline $\begin{array}{l}\text { 5.Tidak melakukan promosi } \\
\text { produk }\end{array}$ & 0,05 & 3 & 0,15 & $\begin{array}{l}\text { 5. Tetap melakukan } \\
\text { pemasaran sendiri }\end{array}$ & 0,03 & 4 & 0,12 & $\begin{array}{l}\text { 5. Penetapan harga } \\
\text { mengikuti harga posko }\end{array}$ & 0,07 & 2 & 0,14 \\
\hline Jumlah & 0,33 & & 1,01 & & 0,34 & & 1,13 & & 0,45 & & 1,17 \\
\hline
\end{tabular}




\section{JIIA, VOLUME 6, No. 1, FEBRUARI 2018}

Tabel 4. Matriks EFAS (Eksternal Factors Analysis Summary) usaha ternak ayam ras petelur skala besar, skala menengah, dan skala kecil untuk kekuatan dan kelemahan di Kecamatan Gadingrejo, tahun 2016

\begin{tabular}{|c|c|c|c|c|c|c|c|c|c|c|c|c|}
\hline \multicolumn{2}{|r|}{ Skala Besar } & Bobot & Rating & Skor & Skala Menengah & Bobot & Rating & Skor & Skala Kecil & Bobot & Rating & Skor \\
\hline \multicolumn{13}{|c|}{ A. Peluang } \\
\hline 1 & $\begin{array}{l}\text { Distributor pakan } \\
\text { dan bibit bagi } \\
\text { peternak kecil }\end{array}$ & 0,14 & 3 & 0,42 & $\begin{array}{l}\text { 1. Ketersediaan lembaga } \\
\text { keuangan yang mudah } \\
\text { dijangkau }\end{array}$ & 0,10 & 4 & 0,40 & $\begin{array}{l}\text { 1. Ketersediaan lembaga } \\
\text { keuangan dengan bunga } \\
\text { kredit pinjaman rendah }\end{array}$ & 0,10 & 2 & 0,20 \\
\hline 2 & $\begin{array}{l}\text { Potensi } \\
\text { pengembangan } \\
\text { daerah sentra ternak }\end{array}$ & 0,14 & 3 & 0,42 & $\begin{array}{l}\text { 2. Ketersediaan tenaga kerja } \\
\text { melimpah }\end{array}$ & 0,10 & 4 & 0,40 & $\begin{array}{l}\text { 2. Potensi pengembangan } \\
\text { daerah sentra ternak ayam } \\
\text { ras petelur }\end{array}$ & 0,10 & 2 & 0,20 \\
\hline 3 & $\begin{array}{l}\text { Informasi mudah } \\
\text { diakses }\end{array}$ & 0,11 & 4 & 0,33 & $\begin{array}{l}\text { 3. Menyediakan lapangan } \\
\text { pekerjaan bagi masyarakat }\end{array}$ & 0,10 & 3 & 0,30 & 3. Informasi mudah diakses & 0,14 & 3 & 0,42 \\
\hline 4 & $\begin{array}{l}\text { Proyeksi } \\
\text { permintaan telur } \\
\text { meningkat }\end{array}$ & 0,16 & 3 & 0,48 & 4. Informasi mudah diakses & 0,10 & 4 & 0,40 & $\begin{array}{l}\text { 4. Permintaan telur } \\
\text { meningkat }\end{array}$ & 0,16 & 3 & 0,48 \\
\hline \multirow{2}{*}{\multicolumn{2}{|c|}{$\begin{array}{l}\text { 5. Kebijakan } \\
\text { pemerintah dalam } \\
\text { mendukung } \\
\text { produksi pakan } \\
\text { ayam }\end{array}$}} & 0,14 & 3 & 0,42 & 5. Permintaan telur meningkat & 0,10 & 3 & 0,30 & $\begin{array}{l}\text { 5. Kebijakan pemerintah } \\
\text { dalam mendukung } \\
\text { produksi pakan ayam }\end{array}$ & 0,14 & 2 & 0,28 \\
\hline & & & & & $\begin{array}{l}\text { 6. Kebijakan pemerintah } \\
\text { dalam mendukung produksi } \\
\text { pakan ayam }\end{array}$ & 0,10 & 2 & 0,20 & & & & \\
\hline \multicolumn{2}{|c|}{ Jumlah } & 0,69 & & 2,07 & & 0,60 & & 2,00 & & 0,64 & & 1,58 \\
\hline \multicolumn{13}{|c|}{ B. Ancaman } \\
\hline \multirow{2}{*}{\multicolumn{2}{|c|}{$\begin{array}{l}\text { 1. Inflasi harga sarana } \\
\text { produksi ternak } \\
\text { 2. Perizinan pembukaan } \\
\text { lokasi baru sulit }\end{array}$}} & 0,13 & 2 & 0,26 & $\begin{array}{l}\text { 1. Peningkatan harga sarana } \\
\text { produksi ternak }\end{array}$ & 0,11 & 2 & 0,22 & $\begin{array}{l}\text { 1. Peningkatan harga sarana } \\
\text { produksi ternak }\end{array}$ & 0,11 & 1 & 0,11 \\
\hline & & 0,04 & 2 & 0,08 & $\begin{array}{l}\text { 2. Penolakan masyarakat atas } \\
\text { didirikannya kandang ayam } \\
\text { baru }\end{array}$ & 0,06 & 2 & 0,12 & $\begin{array}{l}\text { 2. Polusi udara akibat aroma } \\
\text { kandang yang kurang } \\
\text { sedap }\end{array}$ & 0,03 & 4 & 0,12 \\
\hline & $\begin{array}{l}\text { Belum adanya } \\
\text { teknologi penyeteril } \\
\text { kandang dari penyakit } \\
\text { dan virus }\end{array}$ & 0,04 & 2 & 0,08 & $\begin{array}{l}\text { 3. Pengadukan pakan masih } \\
\text { sederhana }\end{array}$ & 0,01 & 3 & 0,03 & $\begin{array}{l}\text { 3. Belum ada teknologi } \\
\text { penyesuaian suhu } \\
\text { kandang }\end{array}$ & 0,07 & 3 & 0,21 \\
\hline & $\begin{array}{l}\text { Pesaing dari usaha } \\
\text { sejenis }\end{array}$ & 0,05 & 3 & 0,15 & 4. Pesaing dari usaha sejenis & 0,11 & 2 & 0,22 & 4. Pesaing dari usaha sejenis & 0,07 & 4 & 0,28 \\
\hline & $\begin{array}{l}\text { Kurangnya riset } \\
\text { teknologi ternak ayam } \\
\text { petelur }\end{array}$ & 0,05 & 2 & 0,20 & $\begin{array}{l}\text { 5. Tidak ada penjaminan } \\
\text { ketersediaan stok pakan }\end{array}$ & 0,11 & 2 & 0,22 & $\begin{array}{l}\text { 5. Tidak ada penjaminan } \\
\text { ketersediaan stok pakan }\end{array}$ & 0,08 & 2 & 0,16 \\
\hline \multicolumn{2}{|c|}{ Jumlah } & 0,31 & & 0,77 & & 0,40 & & 0,81 & & 0,36 & & 0,88 \\
\hline
\end{tabular}

